
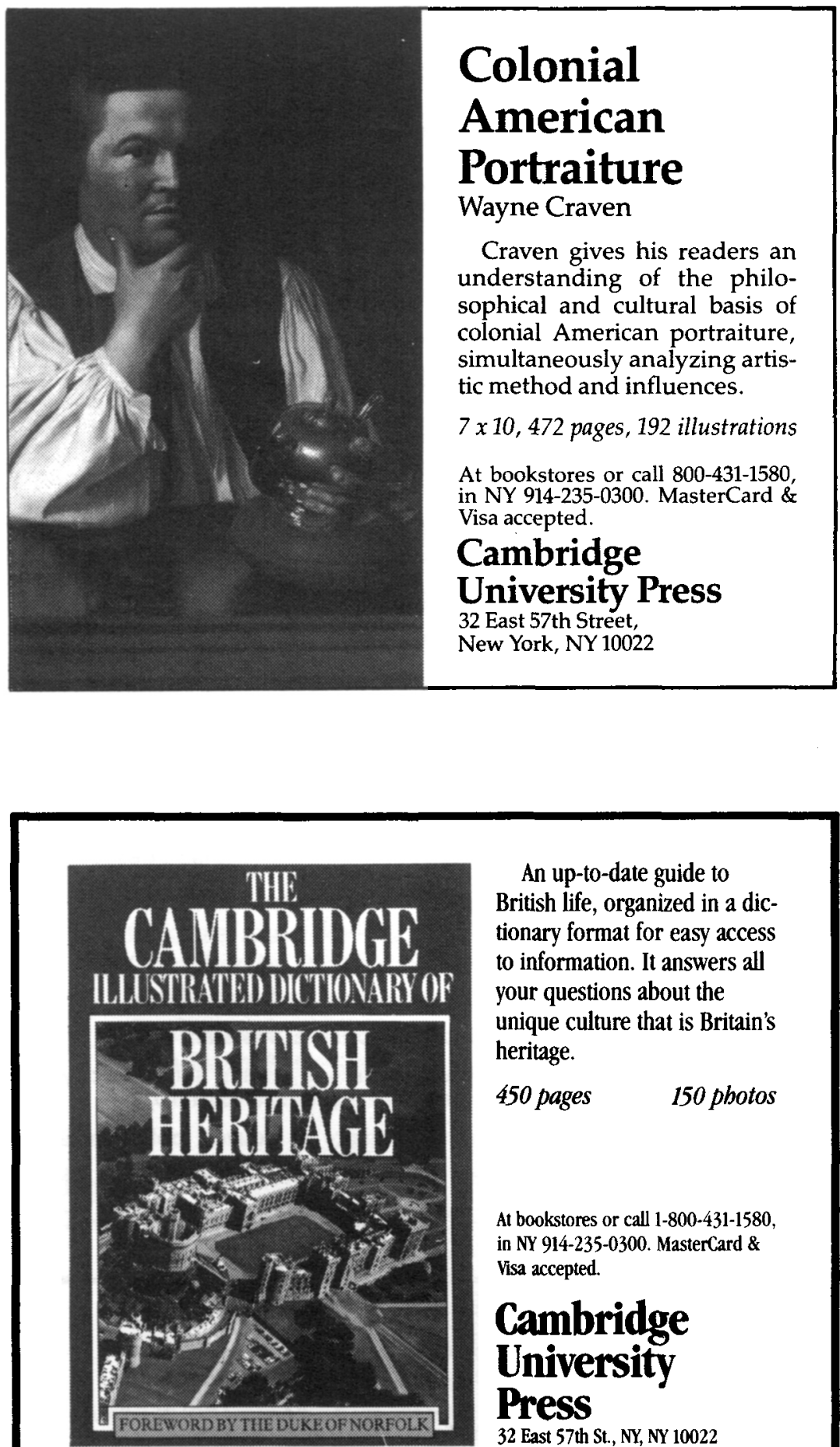

An up-to-date guide to British life, organized in a dictionary format for easy access to information. It answers all your questions about the unique culture that is Britain's heritage.

450 pages

150 pbotos

At bookstores or call 1-800-431-1580, in NY 914-235-0300. MasterCard \& Visa accepted.

\title{
Cambridge University
} Press 


\title{
A n n a 1 es
}

Économies Soctétés Clvilisations

\author{
Fondateure: Lucien FEBVRE ef Mare BLOCH. Directeur : Fernand BRAUDEL. \\ Revue bimestrielle publiée depuis 1929 avec le concours du Centre National de la Recherche Scientifique \\ et de l'École des Hautes Études en Sciences Sociales \\ Comite de Direction : \\ Charles MORAZE \\ André BURGUIERE - Mare FERRO - Jacques LE GOFF \\ Emmanuel LE ROY LADURIE - Jacques REVEL - Lucette VALENSI \\ Secrifalre de la Rodaction : Bernard LEPETIT
}

41. ANNEE - N 5

SEPTEMBRE-OCTOBRE 1986

\section{L'IDENTITE DE L'AUTRE}

François HARTOG, Les Grecs égyptologues

Jean-Claude GALEY, Les angles de I'Inde

L'histoire et ses mythes (comptes rendus)

\section{ÉTAT ET SOCIÉTE SOUS L'ANCIEN RÉGIME}

Christian JOUHAUD, Le duc et l'archevêque : action politique, représentations et pouvoir au temps de Richelieu

Alain GUÉRY, État, classification sociale et compromis sous Louis XIV : la capitation de 1695

Les sociétés d'Ancien Régime (comptes rendus)

\section{L'EUROPE MÉdIÉVALE}

Bronislaw GEREMEK, Marc Bloch, historien et résistant

Patrick J. GEARY, Vivre en conflit dans une France sans État: typologie des mécanismes de règlement des conflits (1050-1200)

Robert J. BARTLETT, Technique militaire et pouvoir politique, 900-1300

Alain GUERREAU, Un tournant de l'historiographie médiévale (Note critique)

\section{RÉDACTION : 54 Boulevard Raspail, 75006 PARIS}

ABONNEMENTS 1987 - France :245 F - Etudiants France : $185 \mathrm{~F}$

- Étranger : $345 \mathrm{~F}$

- Le numero : $65 \mathrm{~F}$ - Le numéro spécial (double) : $130 \mathrm{~F}$

Les abonnements dolvent etre souscrits auprès d'Armand COLIN Éditeur,

103 Boulevard Saint-Michel, 75240 PARIS CEDEX 5

(Comptes chèques postaux : PARIS n॰ 21335-25) 

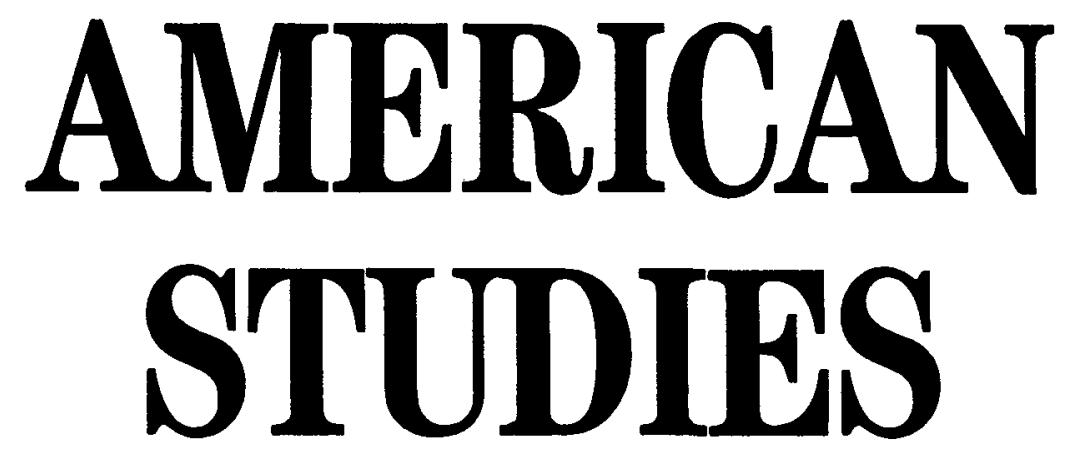

\section{An Annotated Bibliography}

\section{Jack Salzman, Editor \\ Director, Center for American Culture Studies Columbia University}

This major new bibliography - the first-ever of its kind is a thorough listing of American Studies monographs published between 1900 and 1983 .

- Over 8,000 entries in 14 categories such as music, literature, and art and architecture, folklore, and sociology.

- Compiled by the Center for American Culture Studies under the sponsorship of the American Studies Association.

- Handsomely bound in three $61 / 8 \times 91 / 4$ volumes with annual updates scheduled.

$2058 \mathrm{pp}$.

0-521-32555-2 3-volume set $\$ 175.00$

Cambridge University Press

32 East 57th Street

New York, NY 10022 


\section{Published by Cambridge University Press}

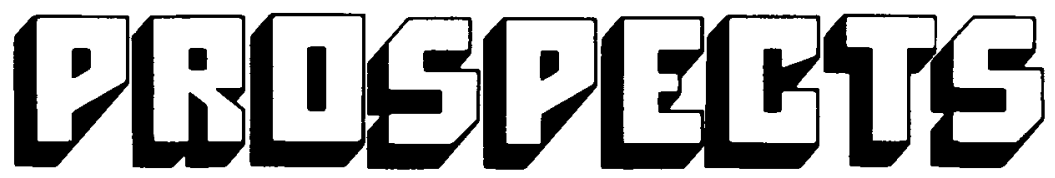

\section{The annual of American Cultural Studies}

Editor: Jack Salzman, Center for American Culture Studies, Columbia University

Prospects, the distinguished annual journal published by Cambridge University Press, explores all aspects of American civilization, including literature, film, humor, satire, photography, music, history, art, urban studies, television and sociology. The journal is neither partisan nor restrictive but has as its prime concern the presentation of exceptional works of criticism and scholarship that elucidate the essential nature of the American character.
Prospects is eclectic in approach: its format is free, open, and flexible, and articles vary considerably in length and subject matter. Each issue is illustrated with line drawings, cartoons, photographs, reproductions of paintings and other graphic art that complement and illustrate the essays.

ASA members may subscribe to Prospects at a special reduced rate.

\section{Order Form}

Please send me Prospects:

$\begin{array}{llcl}\square \text { Volume } 12 \text { (1987) } & \square \text { Volume } 11(1986) \\ \square \text { Institutions } & \$ 68.00 & \square \text { Institution } & \$ 65.00 \\ \square \text { Individual } & \$ 37.00 & \square \text { Individual } & \$ 35.00 \\ \square \text { ASA Member } & \$ 32.00 & \square \text { ASA Member } & \$ 30.00\end{array}$

$\square \mathrm{I}$ am an individual member of the American Studies Association Prices good through December 31, 1987. All individuals must order direct from the Press and prepay by personal check or credit card.

\begin{tabular}{llll} 
& & & \\
Name & & & \\
\hline Citdress & State & Zip
\end{tabular}

$\square$ VISA $\square$ MasterCard (Interbank no. ) Card No.

Send Order To: 


\section{New from Cambridge...}

Culture and Class in Anthropology and History

A Newfoundland Illustration

Gerald M. Sider

“... Greatly enriches our understanding of how people in local communities marshall custom and thought to deal with powerful economic and political forces beyond their ken and control." - Eric $R$. Wolf

"... Controversial... will have to be read and reckoned with by anthropologists, historians - especially colonial American historians - and third world sociologists." - Rhys Isaac $\$ 34.50$

\section{The Social Life of Things \\ Commodities in Cultural Perspective \\ Edited by Arjun Appadurai}

The essays in this volume suggest that there are complex, but specific, social and political mechanisms that regulate taste, trade, and desire.

Contributors: Arjun Appadurai, Igor Kopytoff, William Davenport, Alfred Gell, Colin Renfrew, Patrick Geary, Brian Spooner, Lee Cassanelli, William Reddy, Christopher Bayly. $\$ 37.50$

\section{Ecological Imperialism}

The Biological Expansion of Europe, 900-1900

Alfred W. Crosby

This book is a first step toward the history of the world environment and adds new depth to our understanding the changes wrought by European expansion.

"I commend the book strongly." - William H. McNeill, University of Chicago

Studies in Environment and History

$\$ 22.95$

\section{Human Territoriality}

Its Theory and History

Robert David Sack

This book demonstrates that territoriality for humans is not an instinct, but a powerful and often indispensable geographical strategy used to control people and things by controlling area.

Sack illustrates his theory and history with analysis of the Catholic Church, North American political territorial organization, and the organization of factory, office, and home.

Cambridge Studies in Historical Geography 7

Cloth $\$ 34.50 \quad$ Paper $\$ 12.95$

\section{Worlds Apart}

The Market and the Theater in Anglo-American Thought, 1550-1750 Jean-Christophe Agnew

Agnew traces the history of our concepts of the marketplace and the theater and the ways in which these concepts are bound together. He illuminates one of the most fascinating chapters in the formation of Anglo-American market culture.

$\$ 24.95$

Available at bookstores or call Customer Service at 1-800-431-1580. In NY and Canada 914-235-0300. MasterCard and Visa accepted. 
Comparative Studies in Society and History is a forum for presentation and discussion of new research into problems of change and stability that recur in human societies through time or in the contemporary world. It sets up a working alliance between specialists in all branches of the social sciences and humanities. Debate and review articles bring the general reader in touch with current findings and issues.

\section{NOTES FOR CONTRIBUTORS}

Contributions may be descriptive, analytical or theoretical. Any article not in itself comparative may be accepted if it lends itself to comment that will place it in comparative perspective. Correspondence with the editors prior to the submission of articles will help to enable them to obtain such comment or a companion study. Emphasis in comparative studies may be either on similarities or, if these are significant enough and call for some recasting of generalizations, on differences. All contributions and editorial correspondence should be sent to the Editors, Comparative Studies in Society and History, Department of History, University of Michigan, Ann Arbor, Michigan 48109.

Two copies of each contribution, preferably accompanied by a stamped, addressed envelope, should be submitted. Both text and footnotes should be clearly typed with double spacing and wide margins; footnotes should appear on separate pages at the end of the article. Illustrations may be included by arrangement with the editors. 
Volume $29 \quad$ Number $1 \quad$ January 1987

\section{COMPARATIVE STUDIES IN \\ SOCIETY AND HISTORY}

Editorial Foreword

The Thin Line of Culture

Gerald Sider When Parrots Learn to Talk, and Why They

Can't: Domination, Deception, and Self-Deception in IndianWhite Relations

G. Carter Bentley Ethnicity and Practice

NANCY SCHEPER-Hughes The Best of Two Worlds, the Worst of Two Worlds: Reflections on Culture and Field Work among the Rural Irish and Pueblo Indians

HANS MEDICK "Missionaries in the Row Boat"?

Ethnological Ways of Knowing as a Challenge to Social History

Eve Rosenhaft History, Anthropology, and the Study of Everyday Life. A Review Article

\section{Escaping the State}

Victor Azarya and Naomi Chazan Disengagement from the State in Africa: Reflections on the Experience of Ghana and Guinea

Prasenjit Duara State Involution: A Study of Local

Finances in North China, 1911-1935

CSSH Discussion

Victor B. LiEBERMAN Reinterpreting Burmese History

L. J. JoRDANOVA The Interpretation of Nature. A Review Article

Michael Ruse The Applications of Biology. A Review Article

Cambridge University Press

The Pitt Building, Trumpington Street, Cambridge CB2 IRP

32 East 57 Street, New York, N.Y. 10022

10 Stamford Road, Oakleigh, Melbourne 3166, Australia

(C) 1987 Society for the Comparative Study of Society and History

Printed in the United States of America 